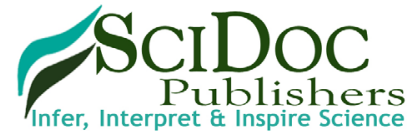

International Journal of Food Science, Nutrition and Dietetics (IJFS)

ISSN 2326-3350

\title{
Nutritional Status Of Migratory Tribal Women Of Punjab
}

\author{
Research Article
}

\author{
Vandana Miglani* \\ ${ }^{1}$ Incharge Dietician, Adesh University, Bathinda, Punjab, India.
}

Abstract

The present study determines the nutritional status of migratory tribal pregnant women of Nakodar, Kapurthala, Jalandhar district in Punjab state [1]. The sample comprised of 50 respondents and information was collected for various parameters including background data, information related to pregnancy, general information about product, storage of food of tribals, dietary assessment for food and nutrient intake, nutrition knowledge, anthropometric and biochemical assessment.

\section{Introduction}

Nutrition is the science of foods, the nutrients and other substances therein; their action, interaction and balance in relation to health and disease. In addition nutrition must be concerned with social, economic, cultural and psychological implication of food and eating. The subject of nutrition is very complex. As a fundamental and necessary part of life, nutrition is related to various aspects of human existence and for every concerned person, it has a different meaning. To the biochemist as a physiological process concerned with; the nutritional status of an organism. To, the physician, it is a primary factor of health and disease, and to the public, it is diet with terms of visual satisfaction, social status, belief and myths [2].

An important aspect of nutrition work is, to attempt to gain valid information regarding what food and how much of them people eat as well as when, where and why. One of the interesting way by which men and women express their choices is through their food-habits. Food-habits are as old as yesterday as contemporary as today and as modern as tomorrow. They vary from one cultural group to another because each group, in its evolution, sets up a complete pattern of standardized behaviour. Individuals within a culture respond to the approved behavioural processes by selecting, consuming and using the food available. On the other hand, choices among food are made only when food is plentiful, enough to permit choices. But where there is lack of food, people cannot have choices as rightly said, "Beggars can't be Choosers." That is the condition which is prevalent in rural areas and low income areas. Due to poverty, malnutrition, exist among these people physi- ological conditions like pregnancy and lactation, aggravates the situation malnutrition $[4,8]$.

The relationship between malnutrition and illness is synergistic. Malnutrition contributes to the frequency and severity of infection in turn depresses the already poor nutritional status [9-11]. This malnutrition generally occurs due to two factors; poverty and ignorance. Pregnancy is a period of great anabolic activity. Popular opinion has long held that the foetus develops at the expense of mother. Both mother and infant suffer due to poor prenatal diet as successful pregnancy requires a continuum of adjustment in maternal body composition, metabolise and the function of various physiological system. A diet that meets maternal nutritional needs is required for these adjustments so that maternal well-being is safeguarded with the birth of healthy, thriving infant and role of nutrition in promoting maternal and infant well-being must always be considered within a broader context $[5,7]$.

Thus role of nutrition during pregnancy cannot be overlooked. Maternal malnutrition is very harmful both for mother and infant. To avoid or to save from this condition people migrate from one place to another in search of food [6]. Food, the prime need of man forces him to migrate in search of food. The current of migration generally flows from the areas of limited economic opportunities and retarded social development to the developed areas, where the migrants can expect enough food and better living [3].

The present study was conducted on migratory tribal pregnant women of Nakodar, Kapurthala, Jalandhar districts in Punjab

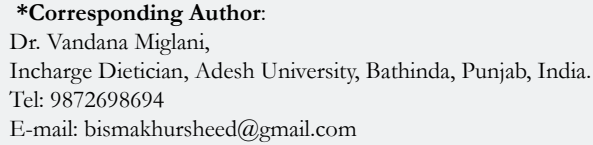

Copyright: Vandana Miglani 2020 . This is an open-access article distributed under the terms of the Creative Commons Attribution License, which permits unrestricted use, distribution and reproduction in any medium, provided the original author and source are credited. 
state [12]. Tribals constitute an important segment of the population of India, representing about eight percent of the total population of the country $[30,33]$. They are distributed in three principal territorial zones of India viz, North eastern Zone, Central Zone, and Southern Zone. Tribals live in certain environment, definite areas with specific food-habits, dialects, cultural homo- geneity and unifying social organization. Because of the scheduled living of the groups, their pattern of living, food and dietary practices and attitudes to various aspects of life-style are generally different from non-tribal population.

All tribal pregnant women surveyed belonged to Mazbi, Gujar \&

Table 1. Distribution According to Tribes in Three Districts.

\begin{tabular}{|c|c|c|c|c|c|}
\hline \multirow{3}{*}{ S. NO. } & \multirow{3}{*}{$\begin{array}{l}\text { NAME OF } \\
\text { DISTRICT }\end{array}$} & & $\mathrm{N}=50$ & & \multirow{3}{*}{ PERCENTAGE \% } \\
\hline & & \multicolumn{3}{|c|}{ NAME OF THE TRIBLES } & \\
\hline & & MAZBI & GUJJAR & SANSI & \\
\hline 1 & Nakodar & 10 & -- & 10 & 40 \\
\hline 2 & Kapurthala & 5 & - & 10 & 30 \\
\hline 3 & Jalandhar & 5 & 10 & -- & 30 \\
\hline
\end{tabular}

Table 2. Distribution According To Age, Size Of Family, Income Level, Gravida, And Trimester Of Pregnancy.

\begin{tabular}{|c|c|c|c|}
\hline S. NO. & AGE GROUP THE SUBJECTS & $\mathrm{N}=\mathbf{5 0}$ & PERCENTAGE \% \\
\hline 1 & Upto 20 Years & 20 & 40 \\
\hline 2 & $20-30$ Years & 30 & 60 \\
\hline S. NO. & SIZE OF FAMILY & $\mathrm{N}=50$ & PERCENTAGE \% \\
\hline 1 & Upto 3 Members (Small) & 5 & 10 \\
\hline 2 & 4-5 Members (Medium) & 20 & 40 \\
\hline 3 & Above 5 Members (Large) & 25 & 50 \\
\hline S. NO. & INCOME LEVEL OF THE SUBJECTS (Rs.) & $\mathrm{N}=50$ & PERCENTAGE \% \\
\hline 1 & Less Than Rs.1000/- & 10 & 20 \\
\hline 2 & Rs.1000/- to $2000 /-$ & 25 & 50 \\
\hline 3 & Rs.2000/- to 3000/- & 15 & 30 \\
\hline S.NO. & GRAVIDA OF PREGNANCY & $\mathrm{N}=50$ & PERCENTAGE \% \\
\hline 1. & Fourth & 14 & 28 \\
\hline 2. & Fifth & 23 & 46 \\
\hline 3. & Sixth & 8 & 16 \\
\hline 4. & Seventh & 5 & 10 \\
\hline S. NO. & $\begin{array}{l}\text { HAEMOGLOBIN gm/dl } \\
\text { LEVEL OF SUBJECTS }\end{array}$ & $\mathrm{N}=50$ & PERCENTAGE \% \\
\hline 1 & $8-9$ & 30 & 60 \\
\hline 2 & $9-10$ & 15 & 30 \\
\hline 3 & $10-11$ & 5 & 10 \\
\hline S. NO. & WEIGHT OF THE SUBJECTS (Kg) & $\mathrm{N}=50$ & PERCENTAGE $\%$ \\
\hline 1 & $40-45$ & 15 & 30 \\
\hline 2 & $45-50$ & 25 & 50 \\
\hline 3 & $50-55$ & 10 & 20 \\
\hline S. NO. & EMI CLASSIFICATION & $\mathrm{N}=50$ & PERCENTAGE \% \\
\hline 1 & Severly Malnourished & 20 & 40 \\
\hline 2 & Moderate Malnourished & 30 & 60 \\
\hline S. NO. & PROBLEM DURING PREVIOUS PREGNANCY & $\mathrm{N}=50$ & PERCENTAGE \% \\
\hline 1 & No Problem & 10 & 20 \\
\hline 2 & Still Birth & 5 & 10 \\
\hline 3 & Abortion & 20 & 40 \\
\hline 4 & $\begin{array}{r}\text { Premature Delivery } \\
\end{array}$ & 15 & 30 \\
\hline S. NO. & COMPLICATION DURING PREGNANCY & $\mathrm{N}=50$ & PERCENTAGE \% \\
\hline 1 & No complication & 10 & -- \\
\hline 2 & Morning Sickness & 40 & -- \\
\hline 3 & Anaemia & 40 & -- \\
\hline 4 & Stomach Pain & 10 & -- \\
\hline 5 & Constipation & 10 & -- \\
\hline S. NO. & CHANGING IN FOOD-HABITS DURING PREGNANCY & $\mathrm{N}=50$ & PERCENTAGE \% \\
\hline 1 & No Change & 15 & -- \\
\hline 2 & Decrease in Amount & 28 & -- \\
\hline 3 & Increase in Amount & 25 & -- \\
\hline 4 & Avoid of fried Foods & 15 & -- \\
\hline 5 & Consume low Spicy Foods & 5 & -- \\
\hline S. NO. & TYPE OF FOOD INTAKE DURING NAUSEA & $\mathrm{N}=50$ & PERCENTAGE $\%$ \\
\hline 1 & No Food & 0 & -- \\
\hline 2 & Semi-Solid & 15 & 30 \\
\hline 3 & Solid & 35 & 70 \\
\hline
\end{tabular}


Sansi. Majority of the respondents belonged to 20-30 years age group. All the respondents were illiterate and they were hawkers by profession. Their monthly income ranged from Rs. 1500-2000 per month (group 2nd income). All the respondents were below poverty line. Majority of the respondents lived in joint families. No landed, proper or 'pucca' houses were available to these respondents. They lived in temporary huts near in the railway lines. $74 \%$ of the respondents were in their third trimester of pregnancy. None of the respondents would go to the hospital for delivery which was performed by an untrained 'daiee' (nurse). Majority of the respondents had no complications except few of them suffered from morning sickness, constipation and stomach-pain [26]. In the present study attempt has been made to assess the nutritional status of tribal pregnant women by means of their food and nutrient intake, anthropometric measurement and biochemical assessment.

Since socioeconomic factors affect the food consumption pattern of tribal pregnant women, therefore a deliberate attempt has been made to analyses the impact of these factors on result obtained from collected data.

Studies conducted on Tribals have shown that there is a direct relationship between age at marriage and fertility [13]. There are some studies conducted on tribes which indicate that women in older age groups always had a tendency to have more briths than younger women.

According to size of family, majority of the subjects were from large families $[17,19,24]$. While $40 \%$ belonged to medium sized families and only $10 \%$ had up to 3 members in their families.

The large families of the tribals show that people still hold the traditional joint family system inspite of their low monthly income [14]. This large family structure influences the nutritional status of pregnant women as her food intake is much lower than required.

According to monthly family income of the subjects. Majority of them had income ranging between 1000 to 2000 Rs. Per month and rest 30\% had income ranging between 2000 to 3000 Rs. Per month and rest $20 \%$ of the subjects belonged to the category of less than $1000[15,16]$.

The low income of the respondents can be attributed to the fact that most of them were hawkers and they had no other means or source of earning money to supplement their income [18].

According to gravida, most of the respondents were multigravide $46 \%$ were having fifth gravida of pregnancy, while $28 \%$ were fourth gravida of pregnancy. Others $16 \%$ had sixth gravida of pregnancy and $12 \%$ had seventh gravida of pregnancy. All the subject were in their 3rd trimester of pregnancy [20].

This shows that the tribals consider their children as an economic asset and made use of their services for work in their occupations as early as possible.

Majority of respondents surveyed were multi gravida. No medical check was being performed during pregnancy. They used common or tribal herbs for common ailments like stomach-pain, common cold etc. All migratory tribal pregnant women surveyed were vegetarians not by choice but due to circumstances like lack of money, basically they were all non-vegetarians. The food consumption pattern was three meals a day [21, 23].

Among cereals, wheat flour was the main staple of the respondents and consumed daily. Rice was rarely consumed. Pulses were an expensive food commodity and was not consumed by them. Among vegetables potato and bottle gourd formed main stay in their diet Frequency of fruit intake was nil [28].

Intake of nutrients among the respondents was lower than the recommended dietary allowances. Average daily intake of energy was $1640 \mathrm{~K} \mathrm{cal}$ as against their RDA of $2525 \mathrm{~K} \mathrm{cal}$. Average daily intake of protein was $35 \mathrm{gms}$ as against their RDA of $65 \mathrm{gms}$. Average daily intake of fat was $25 \mathrm{gms}$ as against their RDA of $30 \mathrm{gms}$. Average daily intake of carbohydrate was $315 \mathrm{gms}$ as against as against their RDA pf 410gms [22, 25].

Daily average intake of micronutrient among the respondents was lower than the recommended dietary allowances. Actual average intake of calcium was $318 \mathrm{mg}$ as against RDA of $1000 \mathrm{mg}$ Actual average intake of iron was $21 \mathrm{mg}$ as against their RDA of 21 mg. 38mg [27]. Actual average intake of Vitamin C was $15 \mathrm{mg}$ as against their RDA of $40 \mathrm{mg}$. All these lower intake level of nutrients were due to very poor economy status of the tribals. They were very poor and could not afford nutritious food during pregnancy. Second factor was due to ignorance, they did not even consume the nutritious food locally available to them [29].

Mean Body weight of the respondents was also recorded and it was below normal. They were in the BMI category which was very severe. Mean haemoglobin level of the tribal pregnant women was $9.09 \mathrm{gm} / \mathrm{dl}[31,32]$.

Overall nutritional knowledge scores obtained by respondent was poor. They had no knowledge regarding conservation of nutrients. Hygiene level of the respondents was very poor. On visit examination their personal hygiene level was assessed and was found to be very low. Neither their hands nor their food stuffs were washed before consumption.

\section{Conclusion}

There is a need of nutrition and health education through proper talks, demonstration, folk medias and audio-visual aids, so that they understand the significance of balanced diets and importance of all the food groups and nutrients in the diet.

Government should provide them land for shelter through tribal welfare schemes as these migratory tribal suffered a lot. They should be provided with employment services/facilities so that they can earn money for their family.

Tribals should be encouraged to have faming as profession. They can be given education to grow all the varieties of food including grains, millets, all types of pulses, vegetables, fruits etc. Government/ Agricultural University/ Non-Voluntary Organizations should help to provide them better facilities, include new variety of seeds, fertilizers and also marketing facilities which will help to improve their economic status and ultimately increase their purchasing power to buy variety to foods which are nutritious for 
them.

They should be made aware of tribal welfare programmes implemented by the Government and should be helped to make use of the opportunities.

Efforts should be made to increase health and medical facilities especially for vulnerable section. Public Health Centers (PHCS) should take care of interior areas.

\section{References}

[1]. Ali A. Food Habits, nutrition health status of the Lanjia Saora - A primitive tribe of Orrissa. Proc. Nutr. Soc. India. 1987; 33: 56-69.

[2]. Al-Ani MR. Diet and dietary habits of nomads in Iraq. Ecology of Food and Nutrition. 1980 Jan 1; 9(1): 55-7.

[3]. Benefice E, Chevassus-Agnes S, Barral H. Nutritional situation and seasonal variations for pastoralist populations of the Sahel (Senegalese Ferlo). Ecology of Food and Nutrition. 1984 Mar 1; 14(3): 229-47.

[4]. Berlin EA, Markell EK. An assessment of the nutritional and health status of an Ayuaruna Jivaro Community Amazonas, Peru, Ecol. Food Nutr. 1977; 6: 69-81.

[5]. Bhardwaj N. Traditional beliefs versus healthy maternal care. Social welfare. 1991; 6: 9-10.

[6]. Chandrasekhar V. Food and food technologies of the mullukurumb as of Nilgiri district Report of field study submitted to the Department of Anthropology (unpublished) Tellichemay. 1990; 23-33.

[7]. Parvathi EP, Goswami B. Nutritive value of selected 15 unconventional plant foods consumed by Khasis of Meghalaya. Indian Journal of Nutrition and Dietetics. 1989; 26: 62.

[8]. Fleuret A. The role of wild foliage plants in the diet: a case study from Lushoto, Tanzania. Ecology of Food and Nutrition. 1979 Jan 1; 8(2): 87-93.

[9]. Gopaldas T. Nutritional status of selected tribes of western and central India. Proceedings of the Nutrition Society of India. 1987; 33: 76-89.

[10]. Gore AP, Shobna T, Kulkarni M. Nutritional status of tribes in the Idravati river basin. Ind. J. Nutr. Dietet. 1977; 14: 167-171.

[11]. Horweg J, Niemeyer R. Preliminary studies on some aspects of kikjuju food habits. Ecol. Food Nutr. 1980; 9:139-150.

[12]. Hunt IF, Murphy NJ, Martner-Hewar PM, Faraji B, Swendseid ME, Reyanolds RD. et al. Zine, vit. B6 and other nutrients in pregnant women attending prenatal clinics in Mexico. Am. J. Clin Nutr. 1987; 46: 563.

[13]. Joseph FG. Influence of development factors on nutritional patterns in the Solomon Islands. Ecol. Food Nutr. 1981; 10: 187-191.
[14]. Kattakayam JJ. Social structure and change among the tribals -A study among the Warlies of Indukki district in Kerala. D.K. Publications, Delhi. 1983; 124-126.

[15]. Kaur. Traditional beliefs versus healthy maternal care. Social welfare. 1995; 6: 9-10.

[16]. National Institute of Nutrition. Annusl Report, Indian Council of Medical Research, Hyderbad. 1983; 199-200.

[17]. Nutrition Neww, National Institute of Nutrition. Hydrabad. 1986; 7: 24

[18]. Nutrition News. National Institute of Nutrition. Hyderabad. 1996; 17: 2.

[19]. Onuoha GB. The changing scene of food habits and beliefs among the Mbaise people of Nigeria. Ecology of Food and Nutrition. 1982 Feb 1; 11(4): 245-50.

[20]. Mahanti N. Tribal Economy Health And Wasteland Development. InterIndia Publications; 1994.

[21]. Pingle U. Some Studies in Two Tribal Groups of Central India: Part 2: Nutritive importance of foods consumed in two different seasons. Plant foods for Man. 1975 Apr 1; 1(3-4): 195-208.

[22]. Nutritive importance of foods consumed in two different seasons. Plant foods for Man. 1: 195-208.

[23]. Pingle U. Integrated approach to Tribal development and health. Proceedings of Nutrition Society of lndia. 1987; 33: 111-24.

[24]. Pratap DR. The dietary habits and nutritional status of chenchus. Tribals Cultural Research and Training Centre, Tribal Welfare Department, Hyderabad, Government of Andhra Pradesh. 1973.

[25]. Prasant KP. Health Disease and Curring pattern among the mullukurumbas of Nilgiri District (Unpublished) report of field work, Department of Anthropology, Tellicherry. 1990; 23-26.

[26]. Rao DH. The tribal diets, Nutrition, A quarterly Publication of the National Institute of Nutrition. Indian Council of Medical Research, Hyderabad. 1971; 6: 2-9.

[27]. Roy JK, Rao RK. Diets of some Indian tribes. Indian Journal of Medical Research. 1962; 50: 905-15.

[28]. Rizvi SN. Health practices of the Jaunsaris: A sociocultural analysis. Tribal health: Socio-cultural dimensions. 1986 Aug 1; 223-46.

[29]. Sarupria S, Mathews. Food consumption pattern and nutritional status of adolescents belonging to scheduled tribes. Proc. Nutr. Soc. Ind No. 1987; 144.

[30]. Saxena R, Verma M. A note on nutritional aspect of Saharia Tribe, Health Bulletin, RMRC for Tribals, Jabalpur. 1993; 2(3): 4.

[31]. Vincent B. Emancipating the Worli Tribals: the Miranda method. Social Wel. 1993; 8: 12.

[32]. Vijaylakashmi P, Devdas RP. Nutrition and maternal health. Ind. J. Nutr. Dietet. 1985; 22(1):1-5.

[33]. Vijaylakashmi P, Devadas RP. Influence of maternal nutrition selected pregnancy related factor. Proc. Nutr. Soc. India. 1988; $34: 83$. 